\title{
Needs Assessment of Indonesian Language Learning Competencies for Deaf Students
}

\author{
Dwi Wijayanti, Vinsensius Reza Bayu Kurniawan \\ \{dwi.wijayanti@ustjogja.ac.id ${ }^{1}$, reza.kurniawan@ustjogja.ac.id² \\ Universitas Sarjanawiyata Tamansiswa ${ }^{1,2}$
}

\begin{abstract}
The implementation of special education for people with disabilities in Indonesia is still faced with various challenges, one of which is competence of literacy and communication for deaf. This study aims to conduct needs assessment of Indonesian language learning which can be used as criteria to produce Information and Communication Technology (ICT)-based innovative learning. This study was carried out in three special elementary schools in Special Region of Yogyakarta and took three samples of deaf students in each elementary school. The research approach is a descriptivequalitative approach comparing national curriculum for deaf students and actual competencies achieved by students. The result of this study is that deaf students at elementary school had not achieved majority competencies on curriculum. Major competencies which had not been achieved were writing ability, sentence composition, and understanding reading text information. The competencies can be used as a reference to develop technology-based interactive learning media.
\end{abstract}

Keywords: needs assessment, Indonesian language, innovative

\section{Introduction}

Education is one of the basic needs for people. UNESCO added that education is human rights for all people. Education provides knowledge, skills, and attitude to compete in the current era of globalization. Indonesia has developed national education system which declared that every citizen has equal rights to have good access of quality education including access of education for people with disabilities. For years, the implementation of education for people with disabilities is still faced with various challenges. The effort to providing quality education service for people with disabilities is often even a controversial issue [1].

The implementation of special education has also been widely discussed in various studies. There are three main aspects related to general education and special education that need to be considered, namely the nature of collaboration, roles of teachers, and outcomes for students and teachers [2]. The others studies explain that the issue of special education and general education brought better educational outcomes for students [3]. The challenge of special education implementation in Indonesia is also faced with various problems. A study in a district in Indonesia concluded that the absence of state-owned rehabilitation centers, lack of competent human resources (special education teachers), lack of cost and infrastructure to encourage the accessibility of education in schools and lack of family support are problems encountered in the implementation of special education [4]. The other challenges are implementing special education teacher task policy such as resources allocation and bureaucratic structure; policy 
communication in the role of special education teacher; and the lack of special education teacher competencies [5]. The detailed challenges of special education challenges in Indonesia are shown in Table 1.

Table 1. Challenges of special education implementation In Indonesia from previous studies

\begin{tabular}{lccc}
\multicolumn{1}{c}{ Problems } & Lestari [4] & Indriawati & Sulistyadi \\
& {$[5]$} & {$[6]$} \\
\hline Absence of stated-owned rehabilitation center & $\sqrt{ }$ & - & $\sqrt{ }$ \\
The lack of competent human resources & $\sqrt{ }$ & $\sqrt{ }$ & $\sqrt{ }$ \\
Lack of special education infrastructure & $\sqrt{ }$ & - & - \\
Negative public perception and family support & $\sqrt{ }$ & - & - \\
Complex bureaucratic structure & - & $\sqrt{ }$ & $\sqrt{ }$ \\
Weak special education policy communication & - & $\sqrt{ }$ & $\sqrt{ }$ \\
Lack of budget and no incentives & - & - & \\
\hline
\end{tabular}

It can be concluded as shown in Table 1 that the majority challenges in the implementation of special education in Indonesia are the lack of competent resources, lack of facilities to support special education, limited budgets and negative public perceptions. Therefore, the implementation of special education for people with disabilities in Indonesia is still with various complex challenges.

The large number of people with disabilities in Indonesia is also a challenge in the implementation of special education. One of the challenges is to provide education for deaf students. Difficulties in hearing for deaf students directly affect the level of literacy and low communication skills. Various studies have been conducted to improve communication skills and literacy level for deaf people. Straetz et al developed the AILB-project, a bilingual webbased learning system for deaf adults to learn mathematical and reading/writing skills. The online learning environment connecting audio, video, and multimedia elements provides a new way for special education teachers to deaf students [7]. In Indonesia, communication skill for deaf people refers to the Indonesian Sign Language System (SIBI). Some researchers have developed various applications to help deaf people in Indonesia interact and socialize, one of application that was developed to introduce English Language as second language for deaf people is DEDALOS[8] and the other is Sign Languange learning application program through hand motion detection using Kinect sensor and dynamic time warping (DTW) methods[9].

Indonesian Language competence for deaf students is a basic ability must be taught to communicate and socialize with all people. As stated in Table 1, the practice of special education in Indonesia including Indonesian language learning for deaf students is still faced with various problems in resources, facilities and curriculum. Those problems provide research opportunities, one of which can produce Indonesian language learning methods in more effective way, perhaps integrating technology, for deaf students. This study aims to assess the needs of Indonesian language learning for deaf students. The results of the needs assessment of Indonesian language learning for deaf students can be used as parameters to design effective learning media according to the users (deaf student needs). 


\section{Method}

This study is qualitative approach study. Needs assessment instruments are carried out for deaf students and special education teachers. Needs assessment instrument for deaf students was conducted to assess the ability to write, tell story or communicate and understand simple vocabularies. Instrument for special education teachers was conducted with semi-structured interviews. This study was conducted in three special schools serving special education for deaf students in Special Region of Yogyakarta with four students in each school. Deaf students who were sample in this study were selected using purposive sampling approach and were students with the best competence of Indonesian language. Deaf students with the best competence of Indonesian language showed the most effective level of indicators achieved according to the curriculum.

\section{Results and Discussion}

Based on the findings of the research team in the field, it figures out that communication for students with hearing impairments is still very difficult. This is because the lack of vocabulary that they have, and the level of Indonesian language skills is still low which include listening skills, reading skills and writing skills. More details can be seen in Table 2

Table 2. Describing Indonesian Language Skills of Deaf Students

\begin{tabular}{|c|c|c|c|c|c|}
\hline \multirow[t]{2}{*}{ Questions } & \multirow[t]{2}{*}{ Competence } & \multicolumn{4}{|c|}{ Sample for School X } \\
\hline & & 1 & 2 & 3 & 4 \\
\hline $\begin{array}{l}\text { 1. Write the contents of the story } \\
\text { from the first video that you } \\
\text { have observed! }\end{array}$ & $\mathrm{U}, \mathrm{R}, \mathrm{W}$ & Enough & Good & Good & Good \\
\hline $\begin{array}{l}\text { 2. Write the contents of the second } \\
\text { video story that you have } \\
\text { observed! }\end{array}$ & $\mathrm{U}, \mathrm{R}, \mathrm{W}$ & Good & Good & Good & Good \\
\hline $\begin{array}{l}\text { 3. Write a story about the daily } \\
\text { activities! }\end{array}$ & $\mathrm{R}, \mathrm{W}$ & Good & Good & Good & Good \\
\hline \multirow[t]{2}{*}{ Questions } & Competence & \multicolumn{4}{|c|}{ Sample for School Y } \\
\hline & & 1 & 2 & $\mathbf{3}$ & 4 \\
\hline $\begin{array}{l}\text { 1. Write the contents of the story } \\
\text { from the first video that you have } \\
\text { observed! }\end{array}$ & $\mathrm{U}, \mathrm{R}, \mathrm{W}$ & Less & Less & Enough & Enough \\
\hline $\begin{array}{l}\text { 2. Write the contents of the second } \\
\text { video story that you have } \\
\text { observed! }\end{array}$ & $\mathrm{U}, \mathrm{R}, \mathrm{W}$ & Less & Less & Enough & Enough \\
\hline $\begin{array}{l}\text { 3. Write a story about the daily } \\
\text { activities! }\end{array}$ & $\mathrm{R}, \mathrm{W}$ & Enough & Enough & Enough & Enough \\
\hline \multirow[t]{2}{*}{ Questions } & Competence & \multicolumn{4}{|c|}{ Sample for School Z } \\
\hline & & 1 & 2 & $\mathbf{3}$ & 4 \\
\hline $\begin{array}{l}\text { 1. Write the contents of the story } \\
\text { from the first video that you } \\
\text { have observed! }\end{array}$ & $\mathrm{U}, \mathrm{R}, \mathrm{W}$ & Less & Less & Less & Less \\
\hline
\end{tabular}




\begin{tabular}{llcccc}
\hline \multicolumn{1}{c}{ Questions } & Competence & \multicolumn{3}{c}{ Sample for School X } \\
\cline { 3 - 5 } & & $\mathbf{1}$ & $\mathbf{2}$ & $\mathbf{3}$ & $\mathbf{4}$ \\
\hline 2. $\begin{array}{l}\text { Write the contents of the second } \\
\text { video story that you have } \\
\text { observed! }\end{array}$ & $\mathrm{U}, \mathrm{R}, \mathrm{W}$ & Less & Less & Less & Less \\
3. & & & & & \\
$\begin{array}{l}\text { Write a story about the daily } \\
\text { activities! }\end{array}$ & R, W & Less & Less & Less & Less \\
\hline
\end{tabular}

NB: All questions represent cognitive and skill aspect

U : Understanding reading text skill

R : Reading skill

W : Writing skill

Based on the results of the analysis above, it can be seen that students with hearing impairments do not have adequate communication skills. From 12 samples of students observed, there are only 4 students had good abilities, 2 students were capable enough, and 6 students were less capable. 4 deaf students in school $\mathrm{X}$ are able to listen to the story of the video (plot, character, message) well, be able to retell the video in their own language, and be able to share their daily activities in paragraph form in a coherent manner using the right vocabulary. 4 Deaf students at school X are taught by the Maternal Reflective Method (MMR) by not using sign language (Non-sign language). MMR is an oral language teaching method that adopts the way of a mother to her children who have not spoken through oral conversation. This method teaches Indonesian language to students without using sign language. In addition, there is also a method "Listen-Say-Say" that students listen to the sentence spoken by the teacher, then the student repeats the sentence that the teacher says with no body movements. Another method used is "Look-Say", the teacher shows the picture and then mentions the name of the picture and the students are asked to listen carefully so that they know what the teacher is carrying. The use of this method aims to equip students to be able to communicate effectively with the general public, especially those who do not understand sign language. However, the application of this method is still experiencing a number of obstacles including the limited number of teachers who understand MMR, the time needed to implement MMR is relatively long, and requires a supportive school environment. In addition to the MMR method, students are also taught to communicate through the method of reading speech.

There are 2 students from school Y who have sufficient abilities, which means they are able to identify characters in the video, retell videos in their own language, and share their daily activities in paragraph form in a coherent manner using the right vocabulary. While 6 students from $\mathrm{Y}$ and $\mathrm{Z}$ schools were less capable, they were only able to identify characters in the video and were able to tell their activities in the form of vocabulary that was still separated. Students in $\mathrm{Y}$ and $\mathrm{Z}$ schools are taught Indonesian language skills by using sign language and combined with the method of reading the utterance and the see-say method. Sign language slows down that the body movements in the form of symbols that are appropriate to describe / describe things that are general, while the speech method is a method of reading lip motion. The weakness of this method is that reading lip movements will be easier to understand for deaf students at the normal level while deaf students at pre-grammar level will not be able to read lip movements so that the communication process will not work. In addition, the use of sign language is not able to equip students to communicate with the wider community who in fact not all can sign language.

Assistive device using artificial neural network system can be used to translate sign language through pattern recognition. The artificial neural network with 4096-75-15 architecture produced the most optimal result with introduction rate of $69 \%$ [6]. Basically the 
communication skills of deaf students are influenced by the ability to speak Indonesian. The more vocabulary you know, it is easier for deaf students to communicate. The variety of vocabulary that introduced to students can be equipped with listening skills, reading skills and writing skills [10]. The Government, through the Ministry of Education and Culture, has set a series of Indonesian-language competencies for students with deafness at the primary and secondary level. But in its application in schools, there are still many Indonesian language competencies that have not been achieved. More clearly can be seen in the Table 3:

Tabel 3. Comparison of Indonesian Language Basic Competencies in 2013 Curriculum with Deaf Students' Actual Ability.

\begin{tabular}{|c|c|c|c|c|c|c|}
\hline \multirow{3}{*}{$\frac{\text { Basic Competence }}{\text { Grade } 2}$} & \multicolumn{6}{|c|}{ Actual Capabulity } \\
\hline & \multicolumn{2}{|c|}{ School X } & \multicolumn{2}{|c|}{ School Y } & \multicolumn{2}{|c|}{ School Z } \\
\hline & $\mathbf{A}$ & NA & $\mathbf{A}$ & NA & $\mathbf{A}$ & NA \\
\hline $\begin{array}{l}\text { 1. Identifying simple descriptive text, Understanding self- } \\
\text { text stories, Observing simple text diagrams both oral and } \\
\text { written. }\end{array}$ & & $\sqrt{ }$ & & $\sqrt{ }$ & & $\sqrt{ }$ \\
\hline $\begin{array}{l}\text { 2. Retelling the text of the self story, composing simple text } \\
\text { diagrams both oral and written, taking into account the use } \\
\text { of standard vocabulary }\end{array}$ & $\sqrt{ }$ & & & $\sqrt{ }$ & & $\sqrt{ }$ \\
\hline \multirow{3}{*}{$\begin{array}{c}\text { Basic Competence } \\
\text { Grade } 3\end{array}$} & \multicolumn{6}{|c|}{ Actual Capability } \\
\hline & \multicolumn{2}{|c|}{ School X } & \multicolumn{2}{|c|}{ School Y } & \multicolumn{2}{|c|}{ School Z } \\
\hline & A & NA & A & NA & A & NA \\
\hline $\begin{array}{l}\text { 1. Observing simple report texts, understand simple } \\
\text { narrative story texts, understand simple poetry texts both } \\
\text { oral and written. }\end{array}$ & $\sqrt{ }$ & & & $\sqrt{ }$ & & $\sqrt{ }$ \\
\hline Basic Competence & \multicolumn{6}{|c|}{ Actual Capability } \\
\hline \multirow[t]{2}{*}{ Grade 3} & \multicolumn{2}{|c|}{ School X } & \multicolumn{2}{|c|}{ School Y } & \multicolumn{2}{|c|}{ School Z } \\
\hline & $\mathbf{A}$ & NA & $\mathbf{A}$ & NA & $\mathbf{A}$ & NA \\
\hline $\begin{array}{l}\text { 2. Composing simple text reports, retelling simple narrative } \\
\text { texts both verbally and in writing with regard to the use } \\
\text { of standard vocabulary, verifying simple poetry lyrics } \\
\text { with pronunciation, intonation, and expressions both } \\
\text { verbally and in writing using the standard of vocabulary } \\
\text { usage. }\end{array}$ & $\sqrt{ }$ & & & $\sqrt{ }$ & & $\sqrt{ }$ \\
\hline
\end{tabular}

\begin{tabular}{|c|c|c|c|c|c|c|}
\hline \multirow{3}{*}{$\begin{array}{c}\text { Basic Competence } \\
\text { Grade } 4\end{array}$} & \multicolumn{6}{|c|}{ Actual Capability } \\
\hline & \multicolumn{2}{|c|}{ School X } & \multicolumn{2}{|c|}{ School Y } & \multicolumn{2}{|c|}{ School Z } \\
\hline & $\mathbf{A}$ & NA & $\mathbf{A}$ & NA & $\mathbf{A}$ & NA \\
\hline $\begin{array}{l}\text { 1. Identifying information from simple report text, } \\
\text { identifying simple diary texts and identifying simple } \\
\text { apologies text. }\end{array}$ & $\sqrt{ }$ & & $\sqrt{ }$ & & $\sqrt{ }$ & \\
\hline $\begin{array}{l}\text { 2. Composing simple text reports, composing a simple text } \\
\text { diary, using a simple apology text using by considering the } \\
\text { standard vocabulary usage and effectiveness of sentences. }\end{array}$ & $\sqrt{ }$ & & $\sqrt{ }$ & & & $\sqrt{ }$ \\
\hline
\end{tabular}

\begin{tabular}{|c|c|c|c|c|}
\hline \multirow{3}{*}{$\begin{array}{c}\text { Basic Competence } \\
\text { Grade } 5\end{array}$} & \multicolumn{4}{|c|}{ Actual Capability } \\
\hline & School X & \multicolumn{2}{|c|}{ School Y } & School Z \\
\hline & A $\quad$ NA & $\mathbf{A}$ & NA & A $\quad$ NA \\
\hline
\end{tabular}
observing referral text / simple instructions, identifying simple myth text both of verbally and in writing. 


\begin{tabular}{|c|c|c|c|c|c|c|}
\hline \multirow{3}{*}{$\begin{array}{c}\text { Basic Competence } \\
\text { Grade } 2\end{array}$} & \multicolumn{6}{|c|}{ Actual Capabulity } \\
\hline & \multicolumn{2}{|c|}{ School X } & \multicolumn{2}{|c|}{ School Y } & \multicolumn{2}{|c|}{ School Z } \\
\hline & $\mathbf{A}$ & NA & $\mathbf{A}$ & NA & $\mathbf{A}$ & NA \\
\hline $\begin{array}{l}\text { 2. Preparing a simple observation report, composing a } \\
\text { referral text / simple instructions, producing the results of } \\
\text { the fairy text identification by considering the use of } \\
\text { standard vocabulary and effectiveness of sentences }\end{array}$ & & $\sqrt{ }$ & & $\sqrt{ }$ & & $\sqrt{ }$ \\
\hline
\end{tabular}
*NB: A (Achieved), NA (Not Achieved)

Based on the table, it could be perceived that the ability of deaf students to achieve basic Indonesian competencies at the primary education level is still relatively low. The basic competencies of Indonesian in the 2013 curriculum have not been able to be fully done in the actual abilities of students.

For school X, with MMR as the learning methods and also supported by IT-based learning facilities, as well as reliable teachers, many students are able to achieve competence well. Even though there are still some students who experience difficulties. Whereas for schools $\mathrm{Y}$ and Z, students' actual abilities are still far below the expected basic competence, especially the competence of retelling texts / passage and composing simple text reports both oral and written by considering to the use of standard and effectiveness of vocabulary.

Based on the results of interviews in May, June and July 2018 to several teachers in schools $\mathrm{X}, \mathrm{Y}$ and $\mathrm{Z}$, it is figured out that there are several factors that influence the communication process of deaf students which including: (1) The lack of vocabulary experienced by the student. This case is one of the determinants of the difficulty in communication for the students. The less vocabulary they mastered, the harder for them to understand words or sentences spoken by others; (2) Imbalance ratio of teacher and student. For students with special needs, Besides having a main teacher in a classroom, they also need special teacher. The teacher is responsible for assisting students more intensely and helping students to understand the learning material delivered by the main teacher. But the reality in the field, deaf students are only taught by classroom teacher and not assisted by assistant teachers. Therefore,the teacher does not have enough time to accompany students one by one in understanding the vocabulary / or sentence which are being taught; (3) Media and a monotonous source of learning. One of the important things in the learning process is the existence of learning media. Interactive learning media and varied learning resources can improve student learning motivation so that subject matter can be understood well. But in the field, the use of media and learning resources for new deaf students is limited to whiteboards, stationery, simple teaching aids, books, and teachers. The media provided is not various and other learning resources such as LCDs, projectors, video screenings, films and the use of media games and others to practice listening skills, reading skills and student writing skills are not provided as well. In addition, through interactive learning media, it is expected that students' vocabulary mastery can be increased; (4) Conventional learning methods. The schools $\mathrm{X}$ uses the MMR method, non-sign language and reading speech. Vocabulary mastery of deaf students in these schools is relatively good, but the schools needs to provide variety of other learning methods. As for $\mathrm{Y}$ and $\mathrm{Z}$ schools, the Indonesian language learning process uses methods of reading speech and applying sign language. Vocabulary mastery by students in these schools is still relatively low, Therefore, it requires a variety of interactive learning methods; (5) Inadequate school facilities. Adequate learning facilities can support the learning process to run more effectively and efficiently. But in the field, it was found that learning facilities were still limited, especially for Indonesian language learning. The teacher still prioritizes the use of tools in the classroom, there is not a language laboratory, the schood also does not use adequate technology and so on; and (6) The environment is less 
supportive which makes the learning process is constrained. For deaf students, the ability to communicate is greatly influenced by the people around them. It takes perseverance of people around deaf students to teach new vocabulary. The multimedia application contained Indonesian Language learning material such as example of sentences, practice questions and puzzles, and Sign Language tutorial video can be used as complementary learning media[11].

Based on the results of observations, needs analysis, interviews and documentation that have been conducted by researchers, the following is presented information in terms of achievement competencies and assessment of needs that must be met for Indonesian language subjects for students with listening impairment:

Tabel 4. Need analysis to achieve Indonesian Language Competence

\begin{tabular}{|c|c|c|}
\hline Competence & Skills & Needs Statement \\
\hline $\begin{array}{l}\text { Understanding } \\
\text { and listening } \\
\text { reading text }\end{array}$ & $\begin{array}{l}\text { a. ability to read and } \\
\text { understand the text } \\
\text { b. Ability to identify } \\
\text { information, data and fact } \\
\text { in texts. } \\
\text { c. Ability to identify and } \\
\text { understand texts. }\end{array}$ & $\begin{array}{l}\text { The findings in the field revealed that deaf students } \\
\text { had difficulty in reading and listening. The listening } \\
\text { ability is based on the sense of sight and hearing } \\
\text { remnants (for those who can still hear), therefore, } \\
\text { understanding vocabulary is also difficult. } \\
\text { Vocabulary as a listening learning material is } \\
\text { intended to develop students' words. Students are } \\
\text { directed to get to know, to know the meaning, and to } \\
\text { use the new words they listen to. Therefore, to } \\
\text { improve listening and reading skills, visual and } \\
\text { interactive learning media are needed. }\end{array}$ \\
\hline Writing & $\begin{array}{ll}\text { a. } & \text { Ability to composing } \\
\text { simple descriptive text. } \\
\text { b. Ability to retell } \\
\text { information, data and } \\
\text { facts in speaking. } \\
\text { c. Ability to read, write and } \\
\text { composing simple text. }\end{array}$ & $\begin{array}{l}\text { The findings in the field, the writing skills of deaf } \\
\text { students are still low due to the low ability to listen } \\
\text { and read. The right method for teaching Indonesian } \\
\text { language is needed, as well as interactive visual } \\
\text { learning media. Interactive visual media can } \\
\text { increase student interest and motivation because it is } \\
\text { more interesting. In addition, it is easier for students } \\
\text { to capture the contents of the message and add new } \\
\text { vocabulary which makes the ability to write } \\
\text { automatically can increase. }\end{array}$ \\
\hline $\begin{array}{l}\text { Speaking/ } \\
\text { Communicati } \\
\text { on }\end{array}$ & $\begin{array}{l}\text { a. Ability to understand the } \\
\text { message in form of } \\
\text { symbol, facial expression } \\
\text { and body language. } \\
\text { b. Ability to respond the } \\
\text { message in both oral and } \\
\text { written. }\end{array}$ & $\begin{array}{l}\text { The findings in the field, the communication skills } \\
\text { of deaf students are still low, due to low listening, } \\
\text { reading and writing skills. Their lack of vocabulary } \\
\text { makes the communication process becomes slow } \\
\text { even though they use sign language. Since the deaf } \\
\text { students learn to rely on their sense of sight and } \\
\text { hearing remnants, an interactive visual media is } \\
\text { needed to help them get to know more new } \\
\text { vocabulary. In communicating, the more vocabulary } \\
\text { they have, the easier for them to capture the contents } \\
\text { of the message and respond. }\end{array}$ \\
\hline
\end{tabular}




\section{CONCLUSION}

Communication is basically an important thing for human as social being. One of the determining factors in communication is the ability to speak. For normal humans, speaking is usual activity in everyday life. But it is different from people who experience disability. Deaf people tend to experience difficulties in communicating. They make sense of sight to see gestures, facial expressions and gesture to capture the message conveyed by the communicator and then respond. The message received can be in the form of oral or written message. Therefore the communication skills of deaf people are influenced by listening skills, reading skills and writing skills.Listening skills, reading skills and writing skills are learned by deaf students through Indonesian language subjects. But in the field, the learning process of Indonesian language subjects experienced several obstacles, including the lack of vocabulary owned by students, imbalance ratio of teacher and student, the monotonous of learning media and sources, the conventional learning methods, the inadequate school facilities, and the lack of environment. support. These obstacles make it difficult to achieve Indonesian language competence. The actual ability of deaf students in Indonesian is still low. Therefore we need a visual and interactive learning media. Interactive visual learning media is suitable for deaf students who rely more on the senses of sight and hearing remnants in the learning process. Through interactive visual media, deaf students can improve vocabulary so that their listening skills, reading skills, writing skills, and communication skills are increased.

Acknowledgments. Thank you to the ministry of research technology and higher education who have founded this reseach through the strarter lecturer research scheme for 2018 fiscal year. Thanks also to the Rector of Universitas Sarjanasiyata Tamansiswa who has supported and facilitated researchers through LP3M UST.

\section{References}

[1] Zhang, D., Katsiyannis, A., Ju, S., \& Roberts, E. (2012). Minority \{Representation\} in \{Special\} \{Education\}: 5-\{Year\} \{Trends\}. Journal of Child and Family Studies, 23(1), 118 127. https://doi.org/10.1007/s10826-012-9698-6

[2] Keefe, E., \& Moore, V. (2004). The challenge of co-teaching in inclusive classrooms at the high school level: what the teachers told us. American Secondary Education, 32(3), 77-89.

[3]Ferguson, D. L. (2008). International trends in inclusive education: The continuing challenge to teach each one and everyone. European Journal of Special Needs Education, 23(2), 109-120. https://doi.org/10.1080/08856250801946236

[4]Lestari, E. (2017). Pemenuhan Hak Bagi Penyandang Disabilitas di Kabupeten Semarang Melalui Implementasi Convention on the Rights of person with disabillities (CPRD) dalam Bidang Pendidikan. Integralistik, 1, 1-9.

[5]Indriawati, P. (2013). Implementasi Kebijakan Tugas Guru Pembimbing Khusus pada Pendidikan Inklusif di SD Negeri se-Kecamatan Junrejo Batu, 1, 49-54.

[6]Sulistyadi, H. K. (2014). Implementasi Kebijakan Penyelenggaraan Layanan Pendidikan Inklusif di Kabupaten Sidoarjo. Kebijakan Dan Manajemen Publik, 2, 1-10. https://doi.org/2303-341X

[7]Smith, C. E. ; \& Allman, T. (2010). Meeting the Challenges of Deaf Education Teacher Preparation: Innovative Practices in Online Learning. Journal of Online Learning and Teaching ; Long Beach, 6(2), 523. https://doi.org/10.1088/1748-9326/aabff4 
[8]Drigas, A. S., Vrettaros, J., \& Kouremenos, D. (2004). Teleeducation and e-learning services for teaching English as a second language to Deaf people, whose first language is the Sign Language . WSEAS Transaction on Information Science and Applications, 1(3), 834.

[9]Gunawan, A. A. S. (2013). Pembelajaran Bahasa Isyarat Dengan Kinect Dan Metode Dynamic Time Warping. Universitas Binus, (9), 1-3

[10]Asriani, F. (2010). Bahasa Indonesia Berbasis Jaringan Syaraf Tiruan Perambatan Balik, 14(2), 150-154.

[11]Dawis, et al. 2013. Studi, P., Informatika, T., Komunikasi, F., Informatika, D. A. N., \& Surakarta, U. M. (2013). Aplikasi Multimedia Bahasa Isyarat Dasar Anak Tuna Rungu 6-9 Tahun. 